\title{
THE FOUNDATION OF MIROGOJ AS THE CENTRAL CEMETERY OF ZAGREB ${ }^{1}$
}

\author{
Kristina MILKOVIĆ ${ }^{*}$
}

The paper presents the foundation of Mirogoj in 1876 as the central cemetery of Zagreb. Since the 1850s, Zagreb had been developing as the capital of Croatia in the modern sense of the word, as a Gründerstadt. As early as the 1860s, the public was of the opinion that a central cemetery should be established outside the city limits. This idea came to fruition in the mid-1870s, in the context of urbanization and modernization of the city. The founding of Mirogoj was an expression of modernity and self-awareness of the bourgeois society, as well as the new sensibilities and aesthetics characteristic of the $19^{\text {th }}$ century.

Keywords: Mirogoj, Zagreb, modernization, cultural history of death, cemetery

\section{Introduction}

Mirogoj was founded as the central cemetery of Zagreb in 1876, not only as the most representative, but also as the first urban cemetery to be established outside the city limits. Its creation can be considered from two different perspectives: as an issue of urbanization and construction of a communal infrastructure in Zagreb, but also through the prism of changing attitudes towards death.

When it comes to the attitudes towards death, the $19^{\text {th }}$ century, i.e. from the last decades of the $18^{\text {th }}$ century to 1918 , seems like a special era character-

1 This research has been financed by the Croatian Science Foundation, project IP-2016-06-2015: Modernization of Urban Life in Croatia through the Prism of Communal Infrastructure Development in the $19^{\text {th }}$ and $20^{\text {th }}$ Centuries.

Kristina Milković, Ph.D., University of Zagreb, Faculty of Croatian Studies, Zagreb, Croatia 
ized by a specific sensibility. In Western and Central Europe, this change took place in the last decades of the $18^{\text {th }}$ century, with the emergence of numerous debates on the harmfulness of cemeteries to the health of the population. Due to the growth of medical knowledge and new insights on the human body, people became preoccupied with the dangers posed by the disintegrating body. Such debates resulted in legal measures that started in the Habsburg area in the mid- $18^{\text {th }}$ century and reached their pinnacle with the decree of Joseph II on the prohibition of burials within the city limits. ${ }^{2}$ The relocation of cemeteries outside cities and towns in Western and Central Europe took place gradually during the first half of the $19^{\text {th }}$ century.

Within only two decades, i.e. during the 1850s and 1860s, Zagreb evolved from a city of local significance, with a limited gravitational area, into the country's capital in the modern sense of the word. In its very concept, Mirogoj was to become a representative city cemetery with arcades as a place of bourgeois cult of the dead, as well as of national memory. Due to its arcades, located at the western and partly northern borders of the cemetery, and designed by Herman Bollé, Mirogoj became "one of the most monumental examples of European cemeterial complexes in the $19^{\text {th }}$ century." 3 Although Zagreb was not a fast-growing city of the Western or Central European type and thus did not have to face the issue of overcrowding and other problems that such cities had, the population influx continued steadily in the second half of the $19^{\text {th }}$ century, and thus the question of creating a city cemetery was becoming topical. The authors of the monograph on Mirogoj from 1974 identified the creation of modern Zagreb with the founding of Mirogoj. ${ }^{4}$ In this article, I will concentrate on the time of the most intensive efforts of the city municipality to establish a central cemetery in the period from 1873-1876.

Like other Central European cities, Zagreb had several city cemeteries before the $19^{\text {th }}$ century (St Peter, St Rochus, St George, Holy Cross or the "paupers' cemetery," St Thomas, Orthodox, Jewish) incorporated into the fabric of the city. All these cemeteries had a pronounced confessional character and

2 Dragan Damjanović, “Groblja u Hrvatskoj u 19. i 20. stoljeću: arhitektura i prostorno uređenje” [Cemeteries in Croatia during the $19^{\text {th }}$ and $20^{\text {th }}$ centuries: Architecture and planning], in: Put $u$ vječnost (Zagreb: Galerija Klovićevi dvori and Posmrtna pripomoć, 2016), p. 34.

3 Dragan Damjanović, "Arhitektura zagrebačkog središnjeg groblja Mirogoj, između Italije i srednje Europe" [Architecture of the central cemetery Mirogoj in Zagreb: Between Italy and Central Europe], in: Čovjek i smrt: Teološki, filozofski, bioetički i društveni pristup, editor-in-chief Ivan Markešić (Zagreb: Institut društvenih znanosti Ivo Pilar, Hrvatsko katoličko sveučilište, and Udruga Posmrtna pripomoć, 2017), p. 435.

4 Boris Hutinec, ed., Mirogoj Zagreb (Zagreb: Grafički zavod Hrvatske, “Gradska groblja” Zagreb, 1973), p. 6. 
were located around the respective churches, as their names indicate. ${ }^{5}$ As a burial site, the church area was most highly prized. ${ }^{6}$ Outspoken differences within the class society continued to show after death and more prominent individuals were buried within churches. Everything related to the cemeteries until the late $18^{\text {th }}$ century was generally a domain of the Church.

During the first half of the $19^{\text {th }}$ century, Zagreb was still a city with a limited population, but from the mid- $19^{\text {th }}$ century, when it grew into the country's capital in the modern sense of the word (although still not for all Croatian historical lands), its population started to grow steadily and the city administration predicted that the existing cemeteries would soon become too small. As early as the $1860 \mathrm{~s}$, the need to create a central cemetery was publicly discussed. ${ }^{7}$ The construction of Mirogoj as a common cemetery also had its legal dimension. The beginning of intense efforts in this respect coincided with the appointment of Ban Ivan Mažuranić, whose era was marked by great efficiency in terms of designing and implementing reforms necessary for the civil society. The foundation for establishing a city cemetery was created in 1867 , with the government decision on places that were suitable for cemeteries. ${ }^{8}$ In this context, Mirogoj could become not only a central, but also a common cemetery for all inhabitants of Zagreb, regardless of their religious affiliation.

\section{Choice of the locality: Mirogoj}

During 1873, at the time when the enterprising Pavao Hatz was Zagreb's mayor, the city administration started to work actively on establishing the central Zagreb cemetery.

Before reaching the City Council, urban administration issues were often discussed in specific committees that covered almost all areas of urban life: economy, poverty, law, politics, education, military, construction and fire prevention, and orphanages. When it comes to the establishment of a central city cemetery, the sessions of the City Council mostly ratified solutions that had previously been agreed upon in two committees, those in charge of economy and the cemeteries.

Minutes of the City Council sessions show that the foundation of the new cemetery was largely a financial issue. Funds for the purchase of land for the

5 Krešimir Kosić, "Mirogoj između jučer i sutra" [Mirogoj between yesterday and tomorrow], in: Mirogoj Zagreb, ed. Boris Hutinec, p. 10.

6 Fischer, Vom Gottesacker zum Krematorium, p. 8.

7 Kosić, “Mirogoj između jučer i sutra," p. 14.

8 Damjanović, "Arhitektura zagrebačkog središnjeg groblja," p. 430. 
new cemetery were obtained early in 1872 by reallocating funds from the former cemeterial foundations, ${ }^{9}$ and the Archiepiscopal Chapter agreed to separate the property of cemeterial chapels from that of the cemetery and cede the latter for the establishment of a new cemetery. ${ }^{10}$ During the 1870 s, several different locations for the construction were considered. Although the decision on the final location had not yet been made, preparations for constructing the central cemetery intensified with the purchase of the Mirogoj estate, which belonged to the most prominent man of the Croatian national revival, the late Ljudevit Gaj. The Mirogoj estate was bought at a public auction held at the end of January 1873 on behalf of the City Council by the city councillor Ivan Frankl for a relatively small amount of 21,320 forints, which was to be paid in four equal instalments by the end of the year. ${ }^{11}$

Also, at the beginning of 1873, an ad hoc committee was appointed with the task of drafting a plan for the payment of the cemetery, its location, and its arrangement. Members of this committee were the abovementioned councillor Ivan Frankl, Franjo Huszar, Stjepan Vrabčević, Jakob Weisz, Stjepan Farkaš, Antun Tot, Mirko Božurić, and Aleks Mraović. ${ }^{12}$ When deciding on the municipal budget for 1873 at the end of March that same year, it was decided that councillor Antun Soh would ask the Zagreb Archdiocese to provide the principal funds for the construction of the city cemetery. ${ }^{13}$ Gaj's estate of Mirogoj was bought from the funds of the cemeteries of St Joseph and St Rochus, which amounted to 17,318 forints in total. ${ }^{14}$ The City Council intended to reimburse

9 Državni arhiv u Zagrebu [State Archive in Zagreb, DAZG]-4, Gradsko poglavarstvo Zagreb [City Administration Zagreb, GPZ], Predsjedništvo [Presidency], Zapisnici sjednica gradskog zastupstva siječnja, 6. veljače, 4. i 3. ožujka 1872., §. 44. [Minutes from the Assembly of the City Council from January 30, February 6, March 4 and 3, 1872, \$. 44], p. 206.

10 HR-DAZG-4, GPZ, Predsjedništvo, Zapisnici sjednica gradskog zastupstva, PRS 116, Zapisnik skupštine gradskog zastupstva od 23. listopada 1872., \$. 3. [Presidency, Minutes from the Sessions of the City Council, PRS 116, Minutes from the Assembly of the City Council from October 23, 1872], \$. 3, p. 220.

11 HR-DAZG-4, GPZ, Predsjedništvo, Zapisnici sjednica gradskog zastupstva, PRS 116, Zapisnik skupštine gradskog zastupstva 30. siječnja 1873., §. 2. [Presidency, Minutes from the Sessions of the City Council, PRS 116, Minutes from the Assembly of the City Council from January 30, 1873], §. 2, p. 225.

12 HR-DAZG-4, GPZ, Predsjedništvo, Zapisnici sjednica gradskog zastupstva, PRS 116, Zapisnik skupštine gradskog zastupstva od 30. siječnja 1873., §. 2. [Presidency, Minutes from the Sessions of the City Council, PRS 116, Minutes from the Assembly of the City Council from January 30, 1873], §. 2, p. 225.

13 HR-DAZG-4, GPZ, Predsjedništvo, Zapisnici sjednica gradskog zastupstva, PRS 116, Zapisnik skupštine gradskog zastupstva od 26. ožujka 1873., \$. 2. [Presidency, Minutes from the Sessions of the City Council, PRS 116, Minutes from the Assembly of the City Council from March 26, 1873, §. 2], p. 229.

14 HR-DAZG-4, GPZ, Predsjedništvo, Zapisnici sjednica gradskog zastupstva, PRS 116, Zapisnik skupštine gradskog zastupstva od 18. i sljedećih dana prosinca 1874., §. 20. [Presidency, Minutes 
this amount to the Church by building a Catholic chapel on Mirogoj. ${ }^{15}$ It is interesting to note that the financing of this huge project was not foreseen in the city budget for the current year, and so the initial works, primarily the purchase of the Mirogoj estate, were realized with money that belonged to the previous cemeteries.

Undoubtedly, the construction of Zagreb's communal infrastructure, and especially of Mirogoj, was modelled on other Central European cities. The city councillor and land surveyor Rupert Melkus was of the opinion that he should visit Vienna and Trieste for these "very important undertakings" when it came to building cemeteries and waterworks, and Prague and Pest when it came to sewerage and asphalting streets. At the suggestion of the economic committee, the municipality did grant Melkus 300 forints and a leave to embark on this journey in February $1873 .{ }^{16}$ Thus, it was the city surveyor Melkus who would have the greatest influence on the spatial and architectural design of Mirogoj during the following five years, until 1878. In August 1873, at the suggestion of the cemeterial committee, the City Council accepted the location plan for its construction and decided to sell all the land in Mirogoj that was not needed for the cemetery, and authorized the committee to produce a book of regulations (Propisnik). ${ }^{17}$

Decisions of the City Council were often guided by financial considerations, and it was constantly looking for new sources of income. One of them was leasing the land plots owned by the city. In the meantime, the municipality decided to lease (exarendare) some land plots in Mirogoj to private individuals, but Melkus suggested that such a practice be discontinued, since the tenants were trying to get the most out of the leased land, not paying attention to the damage they caused. As an example of such poor land use, Melkus cited the vineyards leased in 1873. It was also suggested to sell all those lands that were not needed to establish a new cemetery. Melkus also stressed the need to renovate those buildings in Mirogoj that were designated for the priest's apart-

from the Sessions of the City Council, PRS 116, Minutes from the Assembly of the City Council from December 18 and later that month, 1874, \$. 20], p. 270.

15 HR-DAZG-4, GPZ, Predsjedništvo, Zapisnici sjednica gradskog zastupstva, PRS 117, Zapisnik skupštine gradskoga zastupstva od 12. siječnja 1876., §. 7. [Presidency, Minutes from the Sessions of the City Council, PRS 117, Minutes from the Assembly of the City Council from January 12, 1876, §. 7], p. 276.

16 HR-DAZG-4, GPZ, Predsjedništvo, Zapisnici sjednica gradskog zastupstva, PRS 116, Zapisnik skupštine gradskog zastupstva od 30. siječnja 1873., §. 4. [Presidency, Minutes from the Sessions of the City Council, PRS 116, Minutes from the Assembly of the City Council from January 30, 1873, \$. 4], p. 225.

17 HR-DAZG-4, GPZ, Predsjedništvo, Zapisnici sjednica gradskog zastupstva, PRS 116, Zapisnik skupštine gradskog zastupstva od 19. kolovoza 1873., §. 4. [Presidency, Minutes from the Sessions of the City Council, PRS 116, Minutes from the Assembly of the City Council from August 19, 1873, §. 4], p. 235. 
ment, the gravedigger, and the morgue. In the same report to the City Council, he emphasized that Mirogoj was the best choice for the common cemetery, and explicitly expressed the same views that had been present in discussions about cemeteries since the last quarter of the $18^{\text {th }}$ century - primarily health reasons, but also a new attitude towards the dead body, which emerged at the turn of the $19^{\text {th }}$ century: "Since the need to establish a new cemetery has been proven so many times, because the other cemeteries are overcrowded and should not be further used out of health-related and humanitarian considerations, it is suggested that the construction of a new cemetery in Mirogoj should be started this very year." Burials at the existing cemeteries of St Rochus and St Thomas were to be discontinued, and until a new cemetery was built and opened, they were to take place at the cemetery of St Peter. Despite the fact that Melkus emphasized the urgency of solving these problems, the City Council decided to first refer the whole case to the economic committee for consideration, and only then make a final decision..$^{18}$ Although the City Council initially did not accept Melkus' proposal to stop leasing the lands in Mirogoj to private individuals, the next session held ten days later determined that the city itself would take care of their cultivation, which speaks in favour of Melkus' views. ${ }^{19}$

Although the Mirogoj estate was purchased for quite a low price, it was a significant expense for the municipality and proved impossible to pay before the middle of 1874 . The fact that the property was not paid out presented a legal problem, given that the ownership could not be transferred to the municipality and thus the works could not begin. The economic committee proposed to pawn several relief bonds from the so-called "orphanage treasury" to pay the last instalment and transfer the ownership to the municipality, which the City Council accepted. Despite the purchase of the Mirogoj estate, the economic committee suggested another site to be considered as a place for the cemetery: the land near the gunpowder magazine at the railway station or possibly some other place. $^{20}$

\footnotetext{
18 HR-DAZG-4, GPZ, Predsjedništvo, Zapisnici sjednica gradskog zastupstva, PRS 116, Zapisnik skupštine gradskog zastupstva od 11. ožujka 1874., \$. 8. [Presidency, Minutes from the Sessions of the City Council, PRS 116, Minutes from the Assembly of the City Council from March 11, 1874, $\$$. 8], p. 249.

19 HR-DAZG-4, GPZ, Predsjedništvo, Zapisnici sjednica gradskog zastupstva, PRS 116, Zapisnik skupštine gradskog zastupstva od 21. ožujka 1874., §. 2. [Presidency, Minutes from the Sessions of the City Council, PRS 116, Minutes from the Assembly of the City Council from March 21, 1874, §. 2], p. 250.

20 HR-DAZG-4, GPZ, Predsjedništvo, Zapisnici sjednica gradskog zastupstva, PRS 116, Zapisnik skupštine gradskog zastupstva od 16. svibnja 1874., §. 11. [Presidency, Minutes from the Sessions of the City Council, PRS 116, Minutes from the Assembly of the City Council from May 16, 1874, §. 11], p. 255.
} 
Simultaneously with the cemetery, a number of other construction works related to the city's communal infrastructure were carried out in Zagreb, among which the water supply system was of particular importance. Until 1876 , the cost of establishing the cemetery was not included in the regular budget. It was only then that 20,000 forints were allocated for the arrangement of the cemetery, although the budget had already been "exhausted". ${ }^{21}$ In other words, the municipality allocated finances for the city cemetery that did not exist. The minutes further state: "The mentioned cemetery should be completed by the end of this year, or at least the construction should be started as the most urgent among those proposed to the City Council by the committee for investigating the needs and the budget management of the capital city of Zagreb in its report of August 10, 1874." Considering a number of other construction projects related to the modernization and urbanization of $\mathrm{Za}$ greb, the municipality undoubtedly stretched the annual budget far beyond the maximum. The minutes from the session explicitly state the disparity that existed between the city revenues and the investments. ${ }^{22}$ That the costs of the city administration were indeed high can be seen from the proposal of Deputy Mayor Đuro Crnadak, which was not accepted, that a special committee should be elected to study the "organization of other cities" and make a proposal to improve the city administration and reduce the high costs. ${ }^{23}$

The commission considering other locations for the central cemetery came to the same conclusion as engineer Melkus a few months earlier, namely that none of the existing city cemeteries was suitable to become the central one; moreover, the commission stressed the urgency of closing all city cemeteries, especially that of St Rochus and the "paupers' cemetery," and concluded that only Mirogoj was suitable for that purpose. In this sense, some more work had to be done: repairing the apartment for the cemetery supervisor and expanding the morgue and the gravedigger's apartment; also, the city surveyor's office had to approve the project of the cemetery and appoint the committee to finalize the book of regulations that had already been drafted. The commis-

\footnotetext{
21 HR-DAZG-4, GPZ, Predsjedništvo, Zapisnici sjednica gradskog zastupstva, PRS 117, Zapisnik skupštine gradskoga zastupstva od 15. i sljedećih dana mjeseca veljače 1876. [Presidency, Minutes from the Sessions of the City Council, PRS 117, Minutes from the Assembly of the City Council from February 15 and later that month, 1876], p. 271.

22 HR-DAZG-4, GPZ, Predsjedništvo, Zapisnici sjednica gradskog zastupstva, PRS 117, Zapisnik skupštine gradskoga zastupstva od 15. i sljedećih dana mjeseca veljače 1876. [Presidency, Minutes from the Sessions of the City Council, PRS 117, Minutes from the Assembly of the City Council from February 15 and later that month, 1876], p. 271.

23 HR-DAZG-4, GPZ, Predsjedništvo, Zapisnici sjednica gradskog zastupstva, PRS 117, Zapisnik skupštine gradskoga zastupstva od 15. i sljedećih dana mjeseca veljače 1876. , §. 14. [Presidency, Minutes from the Sessions of the City Council, PRS 117, Minutes from the Assembly of the City Council from February 15 and later that month, 1876, §. 14], p. 271.
} 
sion suggested that not all the forest in Mirogoj should be cleared, but only the part needed for the cemetery. The City Council accepted all the proposals of the commission and this session can be considered as the one at which the final decision on the location of the central cemetery on Mirogoj was made. Regarding the construction and repair of the said buildings, the City Council decided that the city surveyor should be called in and a cost estimate prepared. Any disputes ("differences") that would arise with the clergy or the Archiepiscopal Chapter were the responsibility of the city administration and were to be resolved "peacefully". ${ }^{24}$ The process of closing some of the other cemeteries did not go smoothly, and two years later the City Council reissued a decision on discontinuing burials at the cemeteries of St George, St Rochus, the Holy Cross, and the "paupers' cemetery" in Pantovčak..$^{25}$

The economic committee proposed that the forest be cleared first in the area marked on the map with numbers I, III, and V, intended for members of the Protestant, Jewish, and Orthodox denominations according to their numbers, while the remainder of the area was to be the Catholic cemetery. The proposed deforestation, however, was entrusted by the City Council to a special committee that was to draft a specific proposal on the area and method of clearing, since - as it was pointed out - the forest was to be transformed into a park. The members of this committee were Conte Ivan Buratti, Josip Siebenschein, and the parish priest Pogledić. ${ }^{26}$ The committee informed the City Council that the oak forest was "in disarray and meagre" and suggested that the forest be completely cleared in sections I, III, and V, making a fence out of the wood and selling the surplus. The committee also suggested that the cemetery be opened as soon as possible to enable the burials for those who wanted it. It was also suggested that, for aesthetic reasons, a wall be erected immediately in the western part of the cemetery. However, the City Council did not accept the proposal, and the committee was given the task to produce a new one, following the example of the "tasteful design of cemeteries" in

\footnotetext{
24 HR-DAZG-4, GPZ, Predsjedništvo, Zapisnici sjednica gradskog zastupstva, PRS 116, Zapisnik skupštine gradskog zastupstva od 3. srpnja 1874., \$. 5. [Presidency, Minutes from the Sessions of the City Council, PRS 116, Minutes from the Assembly of the City Council from July 3, 1874, §. 5], p. 258.

25 HR-DAZG-4, GPZ, Predsjedništvo, Zapisnici sjednica gradskog zastupstva, PRS 117, Zapisnik skupštine gradskoga zastupstva od 27. svibnja 1876., §. 9. [Presidency, Minutes from the Sessions of the City Council, PRS 117, Minutes from the Assembly of the City Council from May 27, 1876, \$. 9], p. 286.

26 HR-DAZG-4, GPZ, Predsjedništvo, Zapisnici sjednica gradskog zastupstva, PRS 116, Zapisnik skupštine gradskog zastupstva od 22. i sljedećih dana rujna 1874., \$. 36. [Presidency, Minutes from the Sessions of the City Council, PRS 116, Minutes from the Assembly of the City Council from September 22 and later that month, 1874, §. 36], p. 365.
} 
other cities, especially Verona. ${ }^{27}$ Dragan Damjanović believes that it was then decided to build the arcades modelled on Italian architectural cemeteries. ${ }^{28}$ Indeed, Italian influences can be discerned in the design of Mirogoj (of the architectural cemeteries in Verona, Vicenza, Trieste, Bologna, Genoa, and Siena) as well as the Central European ones, and it is a combination of architectural and park cemetery types. ${ }^{29}$ In the Austro-Hungarian Monarchy, this type of cemetery emerged during the 1870 s, including the cemetery in Vienna. ${ }^{30}$ In the spring of 1875 , the city administration sent Melkus, together with councillor Hudovski, on another trip to Italy. Melkus' report from this journey has been preserved, which shows that Melkus planned to build arcades in the western part of the cemetery, facing the city, a Catholic chapel, ${ }^{31}$ and places of worship for the other three religions. Furthermore, "The open part of the cemetery would be styled like a French park, with regular promenades, tree-lined avenues, and a series of circular areas where luxurious family tombs or mausoleums could be built." 32 This was the basis for a new design, made in 1878 by architect Herman Bollé, which still introduced significant changes with regard to Melkus' original project. ${ }^{33}$

\section{The Book of Regulations: Statute of the General Common Cemetery Mirogoj}

At a session of the City Council early in 1876, the city councillor Adolf Hudovski reported that the statute of the common cemetery Mirogoj had been completed and that it would be placed on the agenda for the next assembly, ${ }^{34}$ which also happened. The Statute of Mirogoj shows a high level of formalization in everything related to the treatment of the dead in general, especially the regulations for the burials and the cemeteries, which is in fact one of the most significant features of modernity.

\footnotetext{
27 HR-DAZG-4, GPZ, Predsjedništvo, Zapisnici sjednica gradskog zastupstva, PRS 116, Zapisnik skupštine gradskog zastupstva od 16. studenog 1874., §. 3. [Presidency, Minutes from the Sessions of the City Council, PRS 116, Minutes from the Assembly of the City Council from November 16, 1874, §. 3], p. 268; Damjanović, "Arhitektura zagrebačkog središnjeg groblja,", p. 435.

28 Ibid., p. 434.

29 Ibid., p. 430.

$30 \quad$ Ibid., p. 434

Ibid., p. 436.

Ibid., p. 437.

Ibid., p. 438.

HR-DAZG-4, GPZ, Predsjedništvo, Zapisnici sjednica gradskog zastupstva, PRS 117, Zapisnik skupštine gradskoga zastupstva od 7. siječnja 1876., \$. 4. [Presidency, Minutes from the Sessions of the City Council, PRS 117, Minutes from the Assembly of the City Council from January 7, 1876, §. 4], p. 272.
} 
The City Council even dedicated several of its sessions to discussing the cemetery's statute, which indicates the level of attention paid to this issue and reveals certain details defined by the statute. Moreover, the city councillors were unwilling to even consider individual proposals before the cemeterial committee presented them as a complete solution. ${ }^{35}$

According to the Statute, the cemetery and the cemeterial fund were managed by a committee of the City Council headed by the deputy mayor. ${ }^{36} \mathrm{~A}$ draft of the joint cemetery was accepted as an integral part of the Statute. ${ }^{37}$ Most of the articles were accepted either without change or with minimal changes. Such minor changes included, for example, that the fence between those parts of the cemetery belonging to other religious communities was to be replaced by a low hedge ( $\$ 22)$. However, there were also more important interventions in the content of the draft Statute. The Council decided to set a constant price for certain lands in Mirogoj in order to avoid any arbitrariness ( $\$ 30)$. At the suggestion of the city councillor Nikola Badovinac, the phrase "for all times" was omitted from the text of the Statute because, as Badovinac pointed out, the owners of graves did not have the right to register them as property, and moreover, the cemetery may not remain on Mirogoj forever (\$32).

The content of the Statute shows a high level of regulation in its wording, especially when it comes to buildings. At the suggestion of councillors Suhin and Vancaš, it was pointed out in the Statute that tombs and arcades would be built at the expense of buyers, and that construction had to be approved in advance by the city building authority $(\$ 35)$. The price for the land to build family tombs was set by the Statute at a relatively high amount of 300 forints. ${ }^{38}$ Also, plots for municipal graves were to cost 1 forint and 50 coins for adults and 80 coins for children. Burials without a coffin or bandages was forbidden. ${ }^{39}$

35 HR-DAZG-4, GPZ, Predsjedništvo, Zapisnici sjednica gradskog zastupstva, PRS 117, Zapisnik skupštine gradskoga zastupstva od 12. veljače 1876., \$. 5. [Presidency, Minutes from the Sessions of the City Council, PRS 117, Minutes from the Assembly of the City Council from February 12, 1876, §. 5], p. 276.

36 HR-DAZG-4, GPZ, Predsjedništvo, Zapisnici sjednica gradskog zastupstva, PRS 117, Zapisnik skupštine gradskoga zastupstva od 12. veljače 1876., §. 4. [Presidency, Minutes from the Sessions of the City Council, PRS 117, Minutes from the Assembly of the City Council from February 12, 1876, \$. 4], p. 276.

37 HR-DAZG-4, GPZ, Predsjedništvo, Zapisnici sjednica gradskog zastupstva, PRS 117, Zapisnik skupštine gradskoga zastupstva od 2. lipnja 1876., \$. 7. [Presidency, Minutes from the Sessions of the City Council, PRS 117, Minutes from the Assembly of the City Council from June 2, 1876, §. 7], p. 287.

38 HR-DAZG-4, GPZ, Predsjedništvo, Zapisnici sjednica gradskog zastupstva, PRS 117, Zapisnik skupštine gradskoga zastupstva od 21. siječnja 1876., \$. 4. [Presidency, Minutes from the Sessions of the City Council, PRS 117, Minutes from the Assembly of the City Council from January 21, 1876, \$. 4], p. 274.

39 HR-DAZG-4, GPZ, Predsjedništvo, Zapisnici sjednica gradskog zastupstva, PRS 117, Zapisnik skupštine gradskoga zastupstva od 28. siječnja 1876., §. 3. [Presidency, Minutes from the Sessions of 
As early as 1872 and 1873 , the city administration discussed all important issues related to Mirogoj with the Archiepiscopal Chapter, which - according to Đuro Deželić - not only gave its consent for the construction of a common cemetery for all denominations, but also agreed that the land for that cemetery be procured from the money that belonged to the cemeteries of St George and St Rochus. The only conditions set by the Archiepiscopal Chapter were that the Catholic cemetery should be large enough in regard to Zagreb's population, that a chapel should be built, and that this part of the cemetery should be surrounded by a fence. ${ }^{40}$

The construction of the cemetery obviously reflected the value system as well as the economic strength of the rising bourgeoisie. But the cemetery's connection with the Church and religiosity was not diminished, much less severed: it had only taken on a new form. This conclusion is based on the fact that the establishment of the central cemetery was discussed with the Archiepiscopal Chapter, and that many issues that were in the domain of the Church, such as funerals, were discussed in detail and also agreed upon in cooperation with the Church and the representatives of individual confessions. In that sense, the city councillors decided to omit the chapter on the organization of funerals from the Statute, and to devise a special order for funerals in cooperation with the representatives of the religious communities. ${ }^{41}$ On the occasion of the opening of the new cemetery, a meeting of religious communities was held at which the Catholic parish priests concluded that the cemetery should be opened after building the fence, the chapel, and the mortuary. The cemeterial committee proposed that the morgue be built immediately, while the chapel was to be built within three years, only the crucifix was to be installed at once. ${ }^{42}$

The Statute of the common cemetery was also considered by the government, which sent a remark to the City Council in this regard, referring to the length of time during which graves must not be reused. It was requested to

the City Council, PRS 117, Minutes from the Assembly of the City Council from January 28, 1876, §. 3], p. 275.

40 HR-DAZG-4, GPZ, Predsjedništvo, Zapisnici sjednica gradskog zastupstva, PRS 117, Zapisnik skupštine gradskoga zastupstva od 21. siječnja 1876., §. 2. [Presidency, Minutes from the Sessions of the City Council, PRS 117, Minutes from the Assembly of the City Council from January 21, 1876, §. 2], p. 274.

41 HR-DAZG-4, GPZ, Predsjedništvo, Zapisnici sjednica gradskog zastupstva, PRS 117, Zapisnik skupštine gradskoga zastupstva od 12. veljače 1876., §. 3. [Presidency, Minutes from the Sessions of the City Council, PRS 117, Minutes from the Assembly of the City Council from February 12, 1876, §. 3], p. 276.

42 HR-DAZG-4, GPZ, Predsjedništvo, Zapisnici sjednica gradskog zastupstva, PRS 117, Zapisnik skupštine gradskoga zastupstva od 2. lipnja 1876., \$. 8. [Presidency, Minutes from the Sessions of the City Council, PRS 117, Minutes from the Assembly of the City Council from June 2, 1876, §. 8], p. 287. 
omit the article ( $\$ 48)$ stipulating that graves may be excavated after fifteen years "because, since the soil components are not known, it cannot be stated whether this time is sufficient for the bodies to rot completely." It is interesting to note that the government was more flexible than the city administration concerning the closure of all other cemeteries in the city, although the opposite had been expected, and considered that the article of the Statute stipulating that all city cemeteries should be closed except for that of St Rochus, and that all the dead should be now buried in one cemetery, was unnecessary since - as it was pointed out - there was still space in the Jewish and Orthodox cemeteries, as well as in the cemetery of St Peter. The government also insisted that the Statute be passed - if that had not already been done - with the consent of the spiritual authorities and religious communities. The councillors decided to file an appeal with the government against this provision as it prevented the Statute from being accepted. ${ }^{43}$

At a session in mid-November, councillor Hudovski reported that the common cemetery was opened and ready for use, and that the cemeteries of St Peter and St Thomas, the military cemetery, and the Orthodox and Jewish cemeteries had to be closed down. ${ }^{44}$ At the beginning of 1877, a board of cemetery directors was elected, which included Hinko Janušić, Josip Siebenschein, Naum Mallin, and Vatroslav Egersdorfer. ${ }^{45}$ The treatment of the dead was largely prescribed and formalized. The City Council accepted the instructions for the gravedigger after they were examined by the city coroner (physicist). In this regard, it was determined that corpses may be exhumed only in the presence of the city coroner. The dimensions of the graves, their depth and distance between them were also regulated in detail. ${ }^{46}$

\footnotetext{
43 HR-DAZG-4, GPZ, Predsjedništvo, Zapisnici sjednica gradskog zastupstva, PRS 117, Zapisnik skupštine gradskoga zastupstva od 27. svibnja 1876., §. 8. [Presidency, Minutes from the Sessions of the City Council, PRS 117, Minutes from the Assembly of the City Council from May 27, 1876, §. 8], p. 286.

44 HR-DAZG-4, GPZ, Predsjedništvo, Zapisnici sjednica gradskog zastupstva, PRS 117, Zapisnik skupštine gradskoga zastupstva od 15. i 17. studenog 1876., \$. 18. [Presidency, Minutes from the Sessions of the City Council, PRS 117, Minutes from the Assembly of the City Council from November 15 and 17, 1876, §. 18], p. 299.

45 HR-DAZG-4, GPZ, Predsjedništvo, Zapisnici sjednica gradskog zastupstva, PRS 117, Zapisnik skupštine gradskoga zastupstva od 17. siječnja 1877., \$. 305 [Presidency, Minutes from the Sessions of the City Council, PRS 117, Minutes from the Assembly of the City Council from January 17, 1877, §. 305].

46 It was decreed that graves should be $2 \mathrm{~m}$ long, $1.10 \mathrm{~m}$ wide and $2 \mathrm{~m}$ deep, with a distance of $0.25 \mathrm{~m}$ between them. HR-DAZG-4, GPZ, Predsjedništvo, Zapisnici sjednica gradskog zastupstva, PRS 117, Zapisnik skupštine gradskoga zastupstva od 15. veljače 1877., \$. 7. [Presidency, Minutes from the Sessions of the City Council, PRS 117, Minutes from the Assembly of the City Council from February 15, 1877, §. 7], p. 307.
} 
Although the municipality was financially exhausted by the purchase of the Mirogoj estate and its arrangement, a number of other works were still due. Roads and paths in the cemetery needed to be constructed, ${ }^{47}$ and the road leading to the cemetery had to be illuminated. The purchase of lamps cost the municipality 200 forints, ${ }^{48}$ while the proposal for constructing an access road between Ksaverska Road and Nova Ves via Medveščak was not accepted without difficulties. ${ }^{49}$

\section{The Arcades}

The construction of family tombs in the arcades was to begin as soon as possible, but the cemetery fund lacked the financial means. ${ }^{50}$ Nevertheless, over time the means were accumulated, and the construction of the arcades could begin. Although Mirogoj does not have a pronounced social topography, places in the arcades, due to their high price, could only be purchased by rich sections of the society or for the most deserving individuals at the expense of the city.

At the end of 1877, the transfer of the remains of poet Petar Preradović to Mirogoj and the construction of an arcade for him were discussed. ${ }^{51}$ At the suggestion of Đuro Deželić, who reported to the committee concerning the transfer of Preradovićs bones to Mirogoj, the municipality financed the construction of an arcade with 2,000 forints and the purchase of a grave plot

\footnotetext{
47 HR-DAZG-4, GPZ, Predsjedništvo, Zapisnici sjednica gradskog zastupstva, PRS 117, Zapisnik skupštine gradskoga zastupstva od 16. lipnja 1876., §. 12. [Presidency, Minutes from the Sessions of the City Council, PRS 117, Minutes from the Assembly of the City Council from June 16, 1876, $\$$. 12], p. 288.

48 HR-DAZG-4, GPZ, Predsjedništvo, Zapisnici sjednica gradskog zastupstva, PRS 117, Zapisnik skupštine gradskoga zastupstva od 27. listopada 1877., §. 10. [Presidency, Minutes from the Sessions of the City Council, PRS 117, Minutes from the Assembly of the City Council from October 27, 1877 , \$. 10], p. 325.

49 HR-DAZG-4, GPZ, Predsjedništvo, Zapisnici sjednica gradskog zastupstva, PRS 117, Zapisnik skupštine gradskoga zastupstva od 12. veljače 1876., §. 5. [Presidency, Minutes from the Sessions of the City Council, PRS 117, Minutes from the Assembly of the City Council from February 12, 1876, §. 5], p. 276.

50 HR-DAZG-4, GPZ, Predsjedništvo, Zapisnici sjednica gradskog zastupstva, PRS 117, Zapisnik skupštine gradskoga zastupstva od 12. veljače 1876., §. 6. [Presidency, Minutes from the Sessions of the City Council, PRS 117, Minutes from the Assembly of the City Council from February 12, 1876, \$. 6], p. 276.

51 HR-DAZG-4, GPZ, Predsjedništvo, Zapisnici sjednica gradskog zastupstva, PRS 117, Zapisnik skupštine gradskoga zastupstva od 15. prosinca 1877., §. 12. [Presidency, Minutes from the Sessions of the City Council, PRS 117, Minutes from the Assembly of the City Council from December 15, 1877, §. 12], p. 327.
} 
with 300 forints. A foundation was in charge of maintaining the arcade. ${ }^{52}$ In 1878 , on the initiative of the municipality, the first arcade was built just for Preradović, designed by architect Herman Bollé. ${ }^{53}$

The construction of the Mirogoj arcades was quite expensive, so the first arcade on two pillars was to cost 3,039 forints and 32 coins, and the others 2,374 forints and 15 coins each, while the pavilions following every seventh arcade cost 12,528 forints each. The City Council accepted the proposal of the building committee concerning the design and price of the arcades, as well as the proposal of councillor Eduard Suhin that anyone should be allowed to build arcades, provided that the construction took place under the supervision of the city surveyor. ${ }^{54}$

However, it was not easy for all residents of the wider area of the city to accept Mirogoj as the place to bury their dead, for reasons we can only guess because they are not explicitly mentioned in the minutes, and many appealed to the Council to allow them to continue using their own cemeteries. The Council, in turn, was rather flexible in this regard and was willing to comply with such requests. ${ }^{55}$

\section{Conclusion}

The founding of Mirogoj in 1876 as the central Zagreb cemetery should be viewed from several different perspectives. Primarily, it was a response to the fact that within the existing urban cemeteries there was no longer space to bury the dead, which was first discussed in public as early as the 1860 s. The previous practice of burials within the city limits, primarily around individual churches, was now abandoned, as was the hitherto strictly confessional character of the cemetery. Nevertheless, one cannot speak of the process of

\footnotetext{
52 HR-DAZG-4, GPZ, Predsjedništvo, Zapisnici sjednica gradskog zastupstva, PRS 117, Zapisnik skupštine gradskoga zastupstva od 29. prosinca 1877. i 2. siječnja 1878. [Presidency, Minutes from the Sessions of the City Council, PRS 117, Minutes from the Assembly of the City Council from December 29, 1877 and January 2, 1878], p. 329.

53 Damjanović, “Arhitektura zagrebačkog središnjeg groblja..., p. 440.

54 HR-DAZG-4, GPZ, Predsjedništvo, Zapisnici sjednica gradskog zastupstva, PRS 117, Zapisnik skupštine gradskoga zastupstva od 10. kolovoza 1878., §. 4. [Presidency, Minutes from the Sessions of the City Council, PRS 117, Minutes from the Assembly of the City Council from August 10, 1878, \$. 4], p. 343.

55 This refers to the inhabitants of upper Ilica, Sv. Duh, Fraterščica, Horvati, Trnje, Vrhovac, Črnomerec, Kuniščak, Pantovčak, Jelenovac, Ljubljanica, Jarun, and Čukovići, who appealed to the municipality to allow them to continue using their own cemeteries. HR-DAZG-4, GPZ, Predsjedništvo, Zapisnici sjednica gradskog zastupstva, PRS 117, Zapisnik skupštine gradskoga zastupstva od 8. travnja 1876., §. 4. [Presidency, Minutes from the Sessions of the City Council, PRS 117, Minutes from the Assembly of the City Council from April 8, 1876, §. 4], p. 282.
} 
secularization in this regard, as the Church and religion retained a significant role, but rather of integration of the civil society during the 1870s. On the other hand, the state increasingly intervened in this domain with various regulations.

In a cultural-historical sense, the entire $19^{\text {th }}$ century reflects a change in attitudes towards death, and fascination with death is also noticeable in literature. In that sense, Croatia was comparable to other Western European and Central European countries. Mirogoj also reflects a new aesthetic and a new sensibility of the bourgeois society: cemeteries and graves became places of remembrance, both when the deceased were private persons whose memory was cherished by their families and when they were prominent personalities who were granted a special place in national memory and whose tombs were distinct. 


\section{Bibliography:}

Ariès, Philippe. Bilder zur Geschichte des Todes. Munich and Vienna: Carl Hanser Verlag, 1984.

Assmann, Aleida. Der lange Schatten der Vergangenheit - Erinnerungskultur und Geschichtspolitik. Munich: C.H. Beck, 2006.

Fischer, Norbert. Vom Gottesacker zum Krematorium. Eine Sozialgeschichte der Friedhöfe in Deutschland. Cologne, Weimar, and Vienna: Böhlau, 1996.

Boris Hutinec, ed. Mirogoj Zagreb. Zagreb: Grafički zavod Hrvatske and "Gradska groblja” Zagreb, 1973.

Damjanović, Dragan. “Groblja u Hrvatskoj u 19. i 20. stoljeću: arhitektura i prostorno uređenje" [Cemeteries in Croatia during the $19^{\text {th }}$ and $20^{\text {th }}$ centuries: Architecture and planning], Put u vječnost, 33-43. Zagreb: Galerija Klovićevi dvori and Posmrtna pripomoć, 2016.

"Arhitektura zagrebačkog središnjeg groblja Mirogoj, između Italije i srednje Europe" [Architecture of the central cemetery Mirogoj in Zagreb: Between Italy and Central Europe], in: Čovjek i smrt. Teološki, filozofski, bioetički i društveni pristup, editor-in-chief Ivan Markešić, 429-459. Zagreb: Institut društvenih znanosti Ivo Pilar, Hrvatsko katoličko sveučilište, and Udruga Posmrtna pripomoć, 2017.

Kosić, Krešimir. "Mirogoj između jučer i sutra” [Mirogoj between yesterday and tomorrow], in: Mirogoj Zagreb, ed. Boris Hutinec, 10. Zagreb, Grafički zavod Hrvatske and "Gradska groblja” Zagreb, 1973.

Maroević, Ivo. Zagreb njim samim [Zagreb through its own eyes]. Zagreb, 1999.

Milković, Kristina. “Sjeverna i središnja Hrvatska od 1790. do 1918.” [Northern and central Croatia, 1790-1918], in: Temelji moderne Hrvatske. Hrvatske zemlje u "dugom" 19. stoljeću, ed. Vlasta Švoger and Jasna Turkalj, 349378. Zagreb: Matica Hrvatska, 2016.

Praz, Mario. The Romantic Agony. Oxford and New York: Oxford University Press, 1991.

Priante, Monica. "Posljednji gradski pozdrav: smrt i pogrebni rituali u Zagrebu u drugoj polovici 19. stoljeća” [The city's last salute: Death and funerary rituals in Zagreb during the second half of the $19^{\text {th }}$ century], in: Čovjek $i$ smrt. Teološki, filozofski, bioetički i društveni pristup, editor-in-chief Ivan Markešić, 551-571. Zagreb: Institut društvenih znanosti Ivo Pilar, Hrvatsko katoličko sveučilište, and Udruga Posmrtna pripomoć, 2017. 